\title{
PELANGGARAN HAK ASASI MANUSIA DALAM KONFLIK ROHINGYA HUMAN RIGHT VIOLATIONS ON ROHINGYA CONFLICT
}

\section{Angela Merici Siba}

Magister Ilmu Hubungan Internasional Universitas Muhammadiyah Yogya-karta

Email: angelmerici8@gmail.com

\section{Anggi Nurul Qomari'ah}

Magister Ilmu Hubungan Internasional Universitas Muhammadiyah Yogya-karta

Email:, angginurul11@gmail.com,

\begin{abstract}
Abstrak
Konflik yang terjadi di Myanmar antara agama Islam dan Budha berdampak jangka panjang bagi etnis Rohingya yang beragama Islam. Egoisme pemerintah Myanmar yang tidak mengakui adanya etnis Rohingya di Myanmar membuat adanya pelanggaran hak asasi manusia terhadap warga Rohingya. Tulisan ini berusaha menjelaskan tentang konflik yang terjadi di Myanmar sejak diterapkan sebuah kebijakan yang disebut burmanisasi. Burmanisasi merupakan kebijakan yang hanya mengakui adanya agama Budha di Myanmar. Oleh sebab itu, etnis Rohingya yang merupakan salah satu etnis di Myanmar tidak diakui kewarganegaraanya hingga dilakukan tindakan kekerasan dan diskriminasi. Tindakan tersebut seperti pembunuhan, pemerkosaan, pembakaran tempat tinggal, penganiayaan dan penindasan. Akibat dari berbagai tindakan ini, mengakibatkan warga Rohingya mengalami luka hingga akhirnya meninggal dunia. Tercatat bahwa tahun 2017 jumlah korban yang meninggal adalah 13.759 jiwa termasuk anakanak. Berdasarkan jumlah korban dan berbagai tindakan pelanggaran hak asasi manusia, maka tindakan tersebut masuk dalam kejahatan genosida. Sebagian yang merasa tidak nyaman di Myanmar memilih untuk mengungi ke negara-negara terdekat seperti Bangladesh dan Indonesia. Pelanggaran demi pelanggaran yang terjadi membuat respon dari berbagai Negara agar
\end{abstract}


konflik ini segera di selesaikam oleh pemerintah Myanmar.

Kata Kunci: Etnis Rohingya, Burmanisasi, Hak Asasi Manusia dan Genosida

\begin{abstract}
Conflict in Myanmar between Islam and Buddhism has long-term impacts on ethnic Rohingyas who are Muslims. The egoism of the Myanmar government that does not recognize Rohingyas in Myanmar makes human rights violations on Rohingyas. This paper seeks to explain the conflicts that have occurred in Myanmar since the adoption of a policy called Burmanization. Burmanization is a policy that recognizes only Buddhism in Myanmar. Because of that, Rohingya who is one of the ethnic in Myanmar is not recognized citizenship of Myanmar, being discriminated and getting violation act. The Violation act such as murder, rape, arson, abuse and oppression. As a result of these actions, the Rohingyas were injured and died. It is recorded that in 2017 the number of dead victims is 13,759 people including children. Based on the number of victims and various acts of human rights violations, they are included in the crime of genocide. Some of Rohingyas who feel intimidated choose to flee to nearby countries such as Bangladesh and Indonesia. Violation that has been occured, make some response from various country pushing Myanmar Government to resolved the conflict immediately.
\end{abstract}

Keyword: Ethnic Rohingya, Burmanization, Human Rights and Genocide

\section{A. Latar Belakang}

Etnis merupakan sekelompok orang yang memiliki ciri khas dalam hal suku maupun agama. Namun, eksistensi dari sebuah etnis sering menimbulkan terjadinya konflik. Setiap etnis perlu mendapat pengakuan dari pihak lain sebagai bentuk bahwa etnis tersebut ada dan mempunyai ciri khas tersendiri. Ketika etnis dari seseorang atau sekelompok orang tidak diakui, akan timbul rasa tidak nyaman, muncul rasa takut, bahkan merasa terancam. Sebuah etnis akan merasa nyaman apabila mereka diterima dan diakui pada sebuah komunitas besar seperti negara. Dalam sebuah negara terdiri dari keberagaman etnis yang menjadi ciri khas dari negara tersebut. Tetapi ada berbagai permasalahan yang kemudian 
muncul akibat adanya etnis sehingga menyebabkan sebuah negara tidak mengakui etnis tersebut. Didalam sebuah etnis hal yang sangat mendorong terjadinya konflik adalah agama. Agama merupakan pedoman penting manusia dalam kehidupannya setiap hari dan menjadi elemen yang berpengaruh terhadap peradaban manusia. Agama menjadi pembanding tingkat keyakinan seseorang, di mana yang merasa seagama dianggap saudara sedangkan berbeda di- anggap pesaing. Agama, di satu sisi mengajarkan tentang kebaikan serta perdamaian tetapi di sisi lain menjadi alat yang digunakan untuk menciptakan konflik. Contohnya, konflik Israel-Palestina antara Islam dengan Yahudi, konflik di Irlandia Utara antara Katolik dan Protestan, dan konflik Islam-Budha di Rakhine, Myanmar.

Konflik agama di Myanmar antara Islam dan Budha, lebih dikenal dengan sebutan konflik etnis Rohingya dan Rakhine. Meskipun konflik ini terjadi di internal Myanmar tetapi membawa dampak bagi dunia internasional terutama negara-negara yang berdekatan dengan Myanmar seperti Indonesia, Malaysia dan Bangladesh. Etnis Rohingya mendapatkan perlakuan diskriminatif dari pemerintahan
Myamar sehingga banyak yang melarikan diri kemudian mengungsi ke Negara-negara tetangga. Awal pemicu konflik kekerasan etnis Rohingya terjadi pada bulan Juli 2012 dan terus menjadi perbincangan dunia internasional hingga sekarang. Banyak yang mengatakan bahwa konflik ini terjadi antarkaum minoritas dan mayoritas yaitu etnis Budha dan Rohingya yang menempati wilayah Rakhine. Secara umum, kekerasan dipicu oleh kasus pemerkosaan dan pembunuhan terhadap perempuan Budha yang diduga dilakukan oleh laki-laki Muslim, yang kemudian dibalas dengan pembunuhan 10 orang laki-laki Muslim (Raharjo, 2015: 40). Dari kejadian tersebut menyebabkan terjadinya pemberontakan dan perlawanan hingga perlakuan tindakan kekerasan yang terdiri dari pembunuhan, penyiksaan, pembakaran rumah dan pemaksaan untuk meninggalkan tempat tinggalnya. Konflik tersebut terus berlanjut hingga pihak Myanmar tidak mengakui Rohingya sebagai salah satu etnis di negaranya. Tindakan ini menimbulkan ketidaknyamanan- Rohingya serta termasuk dalam pelanggaran Hak Asasi Manusia (HAM).

Hak Asasi Manusia (HAM) 
merupakan hak seseorang untuk hidup nyaman, bebas berpendapat, bebas menganut agamanya tanpa membedakan suku, ras, warna kulit, jenis kelamin, kewarganegaraan, serta tidak mendapat perlakuan yang tidak adil dari pihak lain (Nasution, 2006: 22). HAM bersifat universal di mana hak manusia itu tidak dibedakan berdasarkan agama, ras, suku, bangsa, bahkan jenis kelamin. Tetapi yang terjadi terhadap etnis Rohingya adalah bentuk pelanggaran HAM berat. Mereka tidak diberikan hak untuk hidup secara nyaman serta tidak mendapat pengakuan yang layak sebagai warga negara dari Myanmar. Banyak korban yang akhirnya dibunuh hingga mencari kenyamanan dengan mengungsi ke negara tetangga. Yang memilih tinggal, mendapat perlakuan yang tidak adil serta ditindas oleh warga Myanmar. Sedangkan yang lain memilih untuk mengungsi agar bisa mendapat perlindungan terhadap hak-hak mereka. Akhirnya masyarakat Rohingya mendapatkan status stateless atau tidak mempunyai kewarganegaraan. Konflik ini pun mendapat perhatian dari dunia internasional karena dari negaranya sendiri tidak mau mengakui etnis Rohingya.

\section{B. Framework}

Dalam jurnal ini, penulis menggunakan Konsep konflik etnis menurut Michael E. Brown.

Konflik etnis terjadi dalam tiga level yaitu:

\section{Level sistematik}

Penyebab pertama terjadinya konflik etnis adalah lemahnya otoritas pemerintah, baik nasional maupun internasional, untuk mencegah kelompok-kelompok etnis yang ada untuk saling berkonflik. Otoritas yang ada juga sangat lemah, sehingga tidak mampu menjamin keselamatan individu-individu yang ada di dalam kelompok tersebut (Hartati, 2013: 8). Otoritas tersebut berkaitan dengan sikap dari pemerintah yang memobilisasi tentara serta semua perlatan militer dalam menjaga pemerintahanya. Namun tindakan ini dianggap ancaman oleh pihak lain atau biasa disebut dilemma keamanan. Oleh sebab itu, pihak lain pun melakukan hal yang sama untuk mempertahankan diri (self defense). Hal ini yang dikatakan Brown sebagai security dilemma (dilemma keamanan). Kelompok yang satu tidak menyadari bahwa tindakan self defense berpengaruh terhadap pihak lain. 


\section{Level analisis domestik}

Menurut Brown, level domestic- ini terkait dengan kemampuan- pemerintah untuk memenuhi kehendak rakyatnya, pengaruh nasionalisme dan relasi antarkelompok- etnis didalam masyarakat, serta pengaruh dari proses demokratisasi dalam konteks relasi antarkelompok etnis (Hartati, 2013: 9). Pemerintah harus mampu memenuhi kehendak rakyatnya yang menginginkan keamanan dan stabilitas ekonomi. Kedua aspek ini menuntut pemerintah untuk adil serta merata dalam menyediakan dan memenuhi keinginanan rakyatnya.

Dalam pemerintahan sebuah negara juga harus menerapkan nasionalisme di mana ketika pemerintah harus menerapkan pemikiran bahwa setiap warga negara memikil hak dan kewajiban yang sama. Tetapi ketika pemerintahan yang berkuasa lemah, justru paham nasionalisme berubah berdasarkan perbedaan etnis. Berkaitan dengan demokratisasi antarkelompok, bisa menyebabkan terjadinya konflik akibat demokratisasi langsung yang menyebabkan adanya ke- tidakstabilan politik. Hal ini justru meningkatkan konflik etnis di sebuah wilayah.

\section{Level persepsi}

Beberapa ahli berpendapat, bahwa penyebab terjadinya konflik etnis adalah, karena adanya pemahaman sejarah yang tidak tepat mengenai relasi antara dua atau lebih kelompok etnis (Hartati, 2013: 9). Hal ini disebabkan karena pemahamana tentang sejarah bukan berdasarkan penelitian tetapi berdasarkan rumor, gosip serta legenda yang diceritakan secara turun-temurun. Cerita tersebut akan mengalami perubahan setiap generasi sehingga keakuratan dari cerita tersebut tidak benar. Ada banyak versi cerita sejarah yang terkadang diceritakan dengan memperburuk etnis lain sehingga menimbulkan kebencian terhadap etnis tersebut. Kelompok lain dianggap jahat dan telah merusak sejarah mereka, oleh sebab itu, dapat menimbulkan konflik.

\section{Pembahasan}

\section{Akar Konflik}

Sebelum masuk ke akar konflik, lebih baiknya kita mengetahui tentang negara Myanmar itu sendiri. Wilayah Myanmar terbagi menjadi 7 negara bagian yang dinamai berdasarkan etnis minoritas. Sebagai wilayah yang masuk ke dalam Asia tenggara, Myanmar memiliki 
ibukota di Yangoon dengan dikelilingi oleh banyak Negara yaitu Tiongkok, India, Laos, Thailand dan Bangladesh. Terdapat lebih dari 135 kelompok etnik yang masingmasing memiliki budaya dan bahasanya sendiri-sendiri. Etnis terbesar adalah Burma (Bamar). Mereka berasal dari Sino-Tibet dan tinggal di dataran tengah Myanmar. Agama mayoritas etnis Burma adalah Budha Theravada. Mereka juga menguasai pemerintah dan militer dan tentunya menjadi etnis mayoritas di Myanmar. Namun

\section{Peta Myanmar di ASEAN}

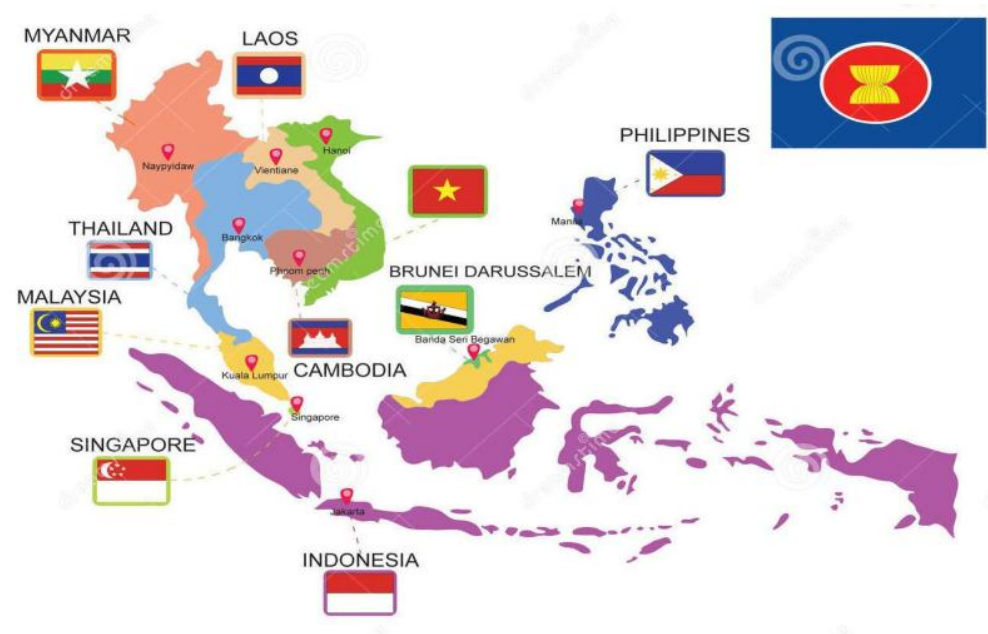

Awal mula konflik ini terjadi sejak pemerintahan Junta Militer merebut kekuasaan melalui kudeta pada tahun 1962, politik diskriminasi terhadap etnik minoritas mulai diberlakukan hal lain terjadi di negara bagian Rakhine yang berbatasan dengan Bangladesh. Di wilayah ini terdapat etnis Rakhine yang beragama Islam/ Arakan. Jumlah etnis Rohingya diperkirakan meliputi $4 \%$ dari penduduk Rakhine, tetapi bila dibanding dengan jumlah penduduk Rakhine yang Budha, muslim Rohingya menjadi kelompok minoritas di Myanmar secara umum jika dibandingkan dengan etnis Burma (Raharjo, 2015: 39). 
berubah menjadi lebih otoriter. Etnis rohingya dianggap rezim $\mathrm{Ne}$ Win sebagai sebuah ancaman sehingga dilancarkanlah sebuah operasi untuk menumpas pergerakan separatis dan mengontrol penduduk Rohingya pada tahun 1978 (Triono, 2014: 2), dan mengakibatkan hijrahnya etnis Rohingya ke Bangladesh. Pada masa rezim Ne Win hingga tahun 2000, etnis Rohingya mengalami keadaan diskriminasi yang sangat berat. Kebijakan Burmanisasi dilakukan melalui marginalisasi orang-orang Muslim Rohingya. Munculnya kebijakan ini pada tahun 1982 yang disebut Burma Citizenship Law (BCL), yaitu Rohingya tidak mendapat kewarganegaraan, hak atas tanah, dan pendidikan serta pekerjaan yang layak dan cukup (Mitzy, 2014: 154) . Akses mereka untuk berpindah, menikah, dan mencari pekerjaan dibatasi dan harus mendapat izin terlebih dahulu dengan membayar uang sogokan. Mereka juga hanya diperbolehkan untuk memiliki maksimal dua anak per keluarga dan tidak diberikan sertifikat kelahiran untuk anak mereka. Hak anak-anak Muslim Rohingya untuk mengakses pendidikan dan pelayanan kesehatan dasar juga sangat dibatasi. Upaya upaya lainnya yang dilakukan junta militer
Myanmar adalah mempengaruhi gaya hidup etnis Rohingya yang beragama Islam untuk pindah ke agama Budha.

Pada masa rezim militer mulai era Ne Win berkuasa hingga tahun 2000, etnis Rohingya mengalami situasi yang berat, hingga puncaknya konflik mengalami eskalasi pada tahun 2012, di mana pemberitaan media internasional mulai membuka fakta-fakta terjadinya konflik yang ada di Rohingya. Adanya kasus ini kemudian memancing etnis Rakhine yang kemudian berujung pada lingkaran konflik yang tidak terhenti. Pada Juli 2012, konflik ini memuncak dengan adanya pembakaran besar-besaran terhadap perumahan yang dihuni oleh etnis Rohingya serta penyerangan yang dilakukan oleh kedua etnis (Triono, 2014: 2 -3). Banyak faktor yang menjadi pemicu awal meledaknya konflik di Provinsi Rakhine terhadap etnis Rohingya. Tidak hanya pemerintahan yang otoriter atau kejam dalam memimpin rakyatnya, tetapi konflik yang terjadi juga terletak pada penggolongan etnis. Akar yang menjadi awal konflik ini terjadi ialah adanya kecemburuan sosial terhadap etnis Rohingya yang dalam beberapa dasawarsa terus meningkat. Meskipun sebagai etnis 
minoritası tetapi etnis Rohingya mampu terlibat dan bekerja dalam pemerintahan Myanmar. Hal ini menyebabkan kecurigaan dan kecemburuan pada etnis mayoritas Rakhine. Bagi mereka keberadaan etnis Rohingya dianggap dianggap sebagai sesuatu yang mengganggu dan mengurangi hak lahan dan ekonomi, khususnya di wilayah Arakan, Rakhine yang menjadi pusat kehidupan etnis Muslim.

Kemudian pada tahun 1962 Undang-Undang Kewarganegaraan Burma tahun 1982 telah meniadakan Rohingya sebagai etnis di Myanmar. Selanjutnya peniadaan ini adalah menghilangkan dan membatasi etnis Rohingya dalam hal yaitu: hak untuk bebas bergerak dan berpindak tempat, hak untuk menikah dan memiliki keturunan, hak atas Pendidikan, hak untuk berusaha dan berdagang, hak untuk bebas berkeyakinan dan beribadah, dan

1 The Largest group in the state are the Rakhine Buddhists, who make up about 60 percent of the 3.2 million total population. Muslim communities, including the Rohingya, are about 30 percent, and the remaining 10 percent consist of Chin (who are Buddhist, Christian, or animist) and a number of other small minorities, including the Kaman (also Muslim), Mro, Khami, Dainet and Marmagyi. Dikutip dalam "Myanmar: The Politics of Rakhine State”, International Crisis Group. hak untuk bebas dari penyiksaan dan kekerasan (Islamedia, 2012). Sejatinya Etnis Rohingya tidak ada niatan memisahkan diri dan merdeka dari Myanmar, mereka hanya ingin diakui sebagai warga negara Myanmar yang berhak untuk hidup bebas dari rasa takut dan kemiskinan serta bebas berekspresi dan beribadah dalam menjalankan agamanya.

\section{Tindakan Pelanggaran Hak Asasi Manusia Terhadap Rohingya}

Konflik etnis antara mayo- ritas Rakhine dan minoritas Rohingya telah berlansung lama yang menyebabkan terjadinya pelanggaran seperti pembunuhan, pembakaran rumah, dan tidak diakui etnis Rohingya sebagai salah satu bagian dari Negara Myanmar. HAM merupakan hak yang melekat kuat dan tidak bisa dipisahkan dari kehidupan manusia. HAM mengalami perkembangan pada tiga generasi. Generasi pertama berkaitan dengan hak sipil dan politik yang berdasarkan pada prinsip kebebasan individu. Generasi kedua berkaitan dengan hak ekonomi, sosial dan kebudayaan yang lebih ditujukan kepada manusia dalam hubungannya dengan kelompok masyarakat lain. 
Generasi ketiga adalah hak -hak asasi manusia, yang menjadi hak bangsa-bangsa dan memperoleh dasarnya dalam solidaritas bangsabangsa, seperti hak bangsa-bangsa untuk menentukan nasib sendiri, hak untuk perdamaian, untuk kemajuan, untuk lingkungan yang layak untuk hidup, dan lain-lain (Baehr, 2001: 10). Namun, dalam kenyataanya di Myanmar hak-hak diatas tidak didapatkan oleh etnis Rohingya. Justru mereka mendapatkan perlakuan tidak adil dari pemerintah Myanmar yang membatasi hak-hak mereka termasuk hak untuk hidup. Pelanggaran HAM yang dilakukan oleh pemerintah Myanmar adalah adanya tindakan pemerkosaan, pembunuhan serta pembakaran rumah- rumah etnis Rohingya. Adapun tindakan diksriminasi yang dilakukan terhadap etnis Rohingya hingga pencabutan kewarga- negaraan mereka. Akhirnya, etnis Rohingya menjadi warga stateless. etnis Rohingya menjadi statelles karena adanya diskriminasi serta pencabutan terhadap status kewarganegaraan. Myanmar meng- hapus Rohingya dari delapan etnis utama yaitu Burmans, Kachin, Karen, Karenni, Chin, Mon, Arakan, Shan, dan dari 135 kelompok etnis lainnya.
Dalam Rome Statute of The International Criminal Court 1998 (Statuta Roma Tahun 1998) dijelaskan mengenai definisi dari pelanggaran HAM. Bentuk-bentuk pelanggaran HAM yang terdapat dalam Statuta Roma berupa kejahatan genosida, kejahatan terhadap kemanusiaan, kejahatan perang, dan kejahatan agresi (Susanti, 2014: 4). Pemerintah Myanamar membuat kebijakan Burmanisasi terhadap warga negara Myanmar yang dengan jelas membuktikan bahwa adanya tindakan diskriminasi. Kebijakan Burmanisasi berarti hanya mengakui adanya agama Budha di Myanmar. Tetapi dalam kenyataannya, ada agama lain yang menetap di Myanmar termasuk Islam (etnis Rohingya). Etnis Rohingya yang terlibat dalam politik pemerintahan Myanmar seperti menteri, sekertaris parlemen, dan sebagian di posisi pemerintahan lainnya, dicabut hingga pemberlakuan hukum bahwa etnis Rohingya maksimal hanya mempunyai dua anak. Tindakan lain yang dilakukan adalah menghapus semua sekolah -sekolah Islam yang selama ini sudah berjalan. Kebijakan ini membuat perlakuan diskriminasi terhadap etnis Rohingya serta pencabutan status kewarganegaraan. Akibatnya, etnis 
Rohingya mencari kenyamanan dengan mengungsi ke beberapa wilayah seperti Malaysia, Indonesia dan Bangladesh. Tentunya etnis Rohingya berhak mendapatkan perlindungan hak asasinya.

Perlakuan buruk yang terjadi terhadap etnis Rohingya telah dijelaskan di bagian akar konflik yaitu ketika masa pemerintahan $\mathrm{Ne}$ Win tahun 1962. Hingga puncaknya pada tahun 2012 di mana penduduk dari etnis Rakhine menyerang bis dan membunuh 10 orang muslim yang diduga oleh etnis Rakhine sebagai Rohingya yang berada dalam bis. Tuduhan tersebut dikarenakan 3 orang Muslim Rohingya telah memperkosa dan membunuh perempuan yang berasal dari etnis Rakhine. Sehingga permasalahan ini meluas hingga menyebabkan ratusan korban kelompok etnis Rohingya, puluhan ribu rumah dibakar, dan ratusan orang ditangkap secara paksa (Susanti, 2014: 5). Tindakan-tindakan kekerasan yang ditujukan kepada kaum Rohingya telah berlansung lama dan akan berpengaruh terhadap psikologi mereka terutama anak-anak. Anakanak yang merasa tidak nyaman dan aka mengalami kesulitan dalam melakukan berbagai tindakan. Tidak hanya anak-anak, orang tua juga akan kesulitan dalam melakukan atau mencari pekerjaan untuk memenuhi kebutuhan setiap hari. Hal ini dikarenakan akses mereka dalam hal mencari pekerjaan bahkan hidup pun diatur dan dilarang oleh pemerintah Myanmar. Oleh sebab itu timbul rasa tidak aman dan merasa nyaman di tempat mereka sendiri dan akhirnya memilih untuk keluar dari Myanmar. Namun, sebagian warga Rohingya masih memilih untuk menetap di Rakhine meskipun keadaan mereka sering terancam dan tidak diakui. Ada alasan kenapa sebagian masyarakat Rohingya masih tetap tinggal di Rakhine karena mereka merasa bahwa Rakhine adalah tempat asal mereka dan sudah sangat lama mereka berdomisili di tempat tersebut. Bahkan sebagian warga pernah terlibat dan berpartisipasi dalam dunia politik Myanmar. Sebagian dari mereka juga mengalami kesulitan dalam mengungsi ke wilayah lain karena akses dan transportasi yang begitu sulit.

Dibawah ini akan dijelaskan tindakan-tindakan pelanggaran HAM serta jumlah korban, yang terjadi di Myanmar dari tahun 2012 sampai 2017, terhadap etnis Rohingya yang dirangkum dari berbagai sumber. 
Tabel bentuk pelanggaran Hak Asasi Manusia terhadap Rohingya

\begin{tabular}{|c|c|c|}
\hline No. & Tahun & Keterangan \\
\hline 1. & 2012 & $\begin{array}{l}\text { Merupakan puncak konflik yang mengakibatkan } 98 \text { orang } \\
\text { terbunuh, } 123 \text { terluka, } 5.338 \text { rumahnya di bakar dan } 75.000 \\
\text { mengungsi. Konflik itu terus memanas sehingga jumlah } \\
\text { korban tahun } 2012 \text { terus mengalami peningkatan yaitu } \\
140.000 \text { etnis Rohingya memilih untuk mengungsi } \\
\text { sedangkan } 120.000 \text { lainnya memilih untuk tetap tinggal di } \\
\text { Rakhine dan hampir } 200 \text { orang meninggal dunia }\end{array}$ \\
\hline 2. & $2013 \mathrm{P}$ & $\begin{array}{l}\text { ara pengungsi yang telah menetap di Bangladesh memilih } \\
\text { untuk meninggalkan Bangladesh serta } 3.000 \text { di antara memilih } \\
\text { untuk mengungsi ke Malaysia, Indonesia dan Thailand }\end{array}$ \\
\hline 3. & 2014 & $\begin{array}{l}\text { Adanya penyerangan dari gerombolan etnis Rakhine yang } \\
\text { mengakibatkan pembunuhan dan dievakuasi } 300 \text { orang serta } \\
140.000 \text { orang terlantar }\end{array}$ \\
\hline 4. & 2015 & $\begin{array}{l}00.000 \text { etnis Rohingya dirampas haknya yaitu tidak diakui } \\
\text { sebagai warga Negara Myanmar. Sedangkan } 30.000 \text { anak } \\
\text { muslim harus kehilangan pendidikan serta tempat untuk } \\
\text { belajar. Adapun total sekitan } 2000 \text { orang yang meninggal } \\
\text { dilaut akibat melarikan diri untuk mengungsi }\end{array}$ \\
\hline 5. & $2016 P$ & $\begin{array}{l}\text { Pada bulan Oktober } 2016 \text { telah terjadi searangan militer oleh } \\
\text { etnis Rokhine yang melakukan pembalasan berupa } \\
\text { pembunuhan, pemerkosaan dan pembakaran yang } \\
\text { mengakibatkan } 100.000 \text { melarikan diri ke Bangladesh }\end{array}$ \\
\hline & \$. 201 & $\begin{array}{l}\text { Merupakan tahun dengan jumlah kekerasan terbanyak selama } \\
\text { konflik etnis Rohingya berlansung. } 9.000 \text { orang meninggal } \\
\text { sejak } 25 \text { Agustus sampai } 24 \text { September. Namun konflik itu } \\
\text { terus mengalami peningkatan. Akhir September meningkat } \\
\text { menjadi } 13.759 \text { orang meninggal termasuk } 1.000 \text { anak usia } \\
\text { dibawah } 5 \text { tahun. Untuk persentasenya: } 69 \% \text { kematian karena } \\
\text { kekerasan, } 9 \% \text { rumah dibakar hingga korban meninggal dan } \\
5 \% \text { dipukuli sampai mati. Untuk anak-anak dibawah } 5 \text { tahun: } \\
59 \% \text { tertembak, 15\% dibakar sampai mati, } 7 \% \text { dipukul hingga } \\
\text { mati dan } 2 \% \text { meninggal karena ledakan ranjau darat. }\end{array}$ \\
\hline
\end{tabular}




$\begin{array}{cl}\text { Sumber: diedit oleh penulis dari } & \text { mengakibatkan jumlah warga } \\ \text { beberap sumber: http://www.bbc. } & \text { Rohingya yang mengungsi terus } \\ \text { com/indonesia/dunia-41105830, } & \text { mengalami peningkatan di beberapa } \\ \text { http://www.msf.org/en/article/ } & \text { Negara seperti Indonesia dan } \\ \text { myanmarbangladesh-msf-surveys- } & \text { Bangladesh. Tindakan yang } \\ \text { estimate-least-6700-rohingya-were- } & \text { dilakukan merupakan tindakan yang } \\ \text { killed-during-attacks, dan } & \text { melanggar Hak Asasi Manusia } \\ \text { http://global.liputan6.com/ } & \text { karena etnis Rohingya merasa tidak } \\ \text { read/3195783/6700-warga- } & \text { nyaman dan merasa hak mereka } \\ \text { rohingya-tewas-dalam-bulan- } & \text { untuk hidup telah dibatasi bahkan } \\ \text { pertama-kekerasan-myanmar } & \text { diambil oleh para militan dari } \\ \text { Setiap tahunnya jumlah korban } & \text { Myanmar. Oleh sebab itu, untuk } \\ \text { pelanggaran Hak Asasi Manusia } & \text { mencari kenyamanan dan } \\ \text { terhadap etnis Rohingya mengalami } & \text { mempertahankan hidup, mereka } \\ \text { peningkatan, terutama tindakan } & \text { memilih untuk mengungsi. Konflik } \\ \text { kekerasan yang menyebabkan warga } & \text { yang memuncak pada tahun 2012 } \\ \text { Rohingya mengungsi. Hingga } & \text { tersebut akhirnya menambah jumlah } \\ \text { sekarang konflik ini belum } & \text { korban pengungsi dalam skala besar } \\ \text { menemukan solusi yang tepat, } & \text { hingga tahun 2017. Pada tahun 2017 } \\ \text { meskipun banyak negara dan } & \text { jumlah korban yang mengungsi ke } \\ \text { organisasi internasional turut serta } & \text { wilayah Bangladesh mengalami } \\ \text { dalam upaya menyelesaikan konflik } & \text { peningkatan yang cukup tinggi. Hal } \\ \text { tersebut. Karena tindakan kekerasan } & \text { ini dapat ditunjukan dalam grafik } \\ \text { yang terus dilakukan } & \text { berikut: }\end{array}$

Grafik jumlah pengungsi di Bangladesh

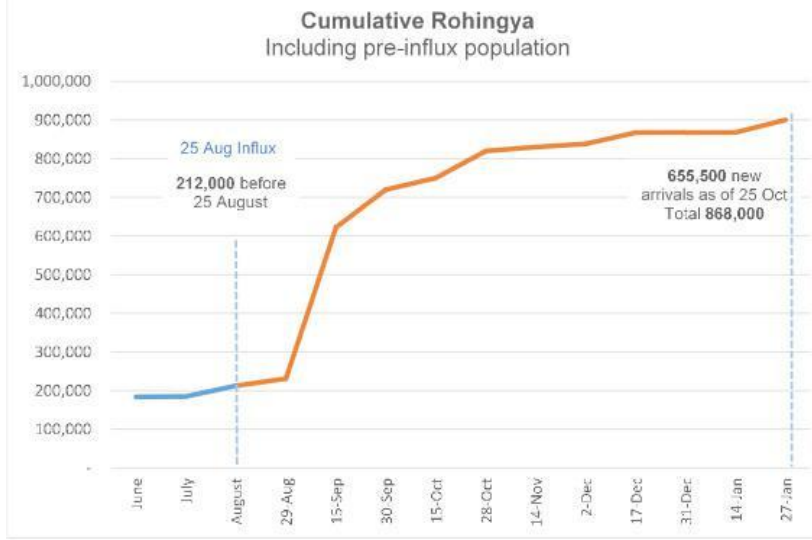


Sumber: https://reliefweb. int/sites/reliefweb.int/files/ resources/180127_weekly_iscg_ sitrep_final.pdf

Grafik tersebut menunjukan bahwa jumlah warga Rohingya di tahun 2017 sampai Januari 2018 mengungsi ke Bangladesh dalam jumlah yang tinggi hingga mencapai 900.000 orang atau jiwa. Dengan demikian, tingkat kenyamanan warga Rohingya di Myanmar tidak terjamin sehingga mereka lebih banyak mengungsi ke negara tetangga. Tidak hanya di Bangladesh, warga Rohingya juga mengungsi ke Indonesia dengan menggunakan perahu-perahu kecil. Jumlah pengungsi di Indonesia tidak sebanyak yang berada di
Bangladesh.

Indonesia sendiri menerima pengungsi Rohingya di penampungan imigrasi. Penampungan Imigrasi Kelas 1 Khusus Medan menampung 319 orang. Rinciannya 144 orang di penampungan Hotel Braspati, 27 orang di penampungan Belawan, 128 orang di penampungan Hotel Pelangi, dan 20 orang di penampungan Hotel Top Inn (Tribun Medan, 2017). Namun, ada pula diagram yang menunjukan jumlah korban Rohingya yang mengungsi ke wilayah Indonesia khususnya di Aceh. Aceeh merupakan wilayah yang paling terbuka dalam menerima pengungsi Rohingya dari awal konflik itu terjadi.

\section{Diagram jumlah pengungsi di Aceh}

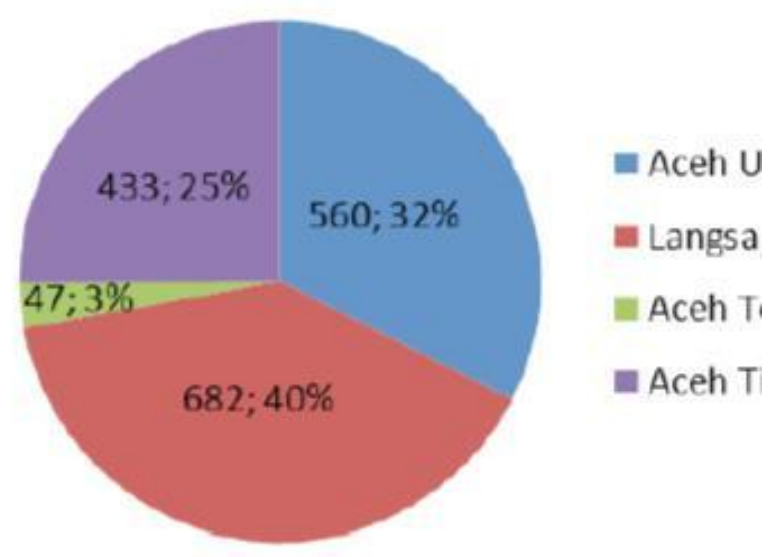

Sumber: Jurnal Indonesian Perspektive, Vol. 2 No. 2, Januari-Juli 2017. Hal. 12 
Jumlah korban ini diambil terkahir pada tahun 2015 dan tentunya akan mengalami pe-ningkatan, karena konflik yang terjadi di Myanmar belum mencapai solusi yang tepat untuk Myanmar sendiri dan juga warga Rohingya. Jika, ditelusuri kembali, konflik yang terjadi sangat berpengaruh terhadap jumlah pengungsi di suatu wilayah. Semakin besar konflik, maka semakin banyak jumlah korban yang mengungsi. Dari jumlah pengungsi yang berada di Indonesia dan Bangladesh dapat diketahui bahwa warga Rohingya belum mendapat perlakuan yang adil serta hak mereka untuk hidup dari pemerintah Myanmar. Oleh sebab itu, masih terus terjadi tindakan pelanggaran hak terhadap warga Rohingya.

Berdasarkan tabel, grafik, dan diagram di atas, penulis dapat menganalisa bahwa konflik yang terjadi di Rohingya masuk ke dalam tindakan pelanggaran HAM berat. Oleh sebab itu, pelanggaran HAM ini masuk ke dalam tindakan Genosida (pembantaian etnis secara besar-besaran)

Genosida merupakan tindakan kejahatan yang berkaitan dengan pemusnahan etnis, ras atau agama. Tindakan tersebut berupa pembunuhan, pembantaian dan tindakan lainnya yang mengakibatkan kerusakan fisik atau mental sebagian orang (etnis tertentu). Genoside dalam Konvensi Pencegahan dan Penghukuman terhadap Kejahatan Genosida (Convention on the Prevention and Punishment of the Crime of Genocide) tahun 1948 adalah suatu tindakan dengan maksud menghancurkan atau memusnahkan seluruh atau sebagian kelompok bangsa, ras, etnis, atau agama (Turangan, 2011:

6). Yang terjadi terhadap etnis Rohingya, masuk dalam salah satu kejahatan genosida. Hal ini dibuktikan dengan data jumlah korban akibat berbagai tindakan kekerasan yang terus mengalami peningkatan sejak tahun 2012. Upaya etnis Rakhine dalam me- lakukan tindakan kekerasan merupakan upaya pemusnahan terhadap etnis Rohingya yang beragama Islam, karena sudah ada kebijakan yang dikeluarkan dari pemerintah Myanmar yaitu burmanisasi. Oleh sebab itu, etnis yang bukan beragama Budha akan dihilangkan dari Myanmar dan salah satunya adalah etnis Rohingya. Tindakan genosida yang dilakukan merupakan tindakan yang sudah direncanakan secara sistematis dalam hal ini dibuktikan dengan mengeluarkan kebijakan burmanisasi. Dari kebijakan tersebut 
terjadi tindakan pembunuhan dan pemusnahan terhadap etnis Rohingya agar Rohingya tidak lagi berada di Myanmar. Adanya kebijakan burmanisasi, membuat etnis dari Myanmar yang merupaka agama Budha dengan sewenangwenang melakukan segala bentuk tindakan dari pembunuhan, pembakaran rumah-rumah hingga tidak mengakui kewarganegaraan seseorang. Tujuannya adalah agar etnis Rohingya dimusnahkan atau keluar dari Myanmar.

Konflik etnis yang telah memakan ribuan korban etnis Rohingya merupakan konflik yang berlangsung sepanjang tahun 2012 sampai 2017 dengan tindakan kekerasan dan jumlah korban yang terus mengalami peningkatan. Hak hak etnis ini telah dirampas dan mereka sama sekali tidak memiliki hak sebagai seorang warga negara termasuk hak untuk hidup. Mereka dibantai, dibunuh bahkan tempat tinggal pun dibakar. Anak-anak yang seharusnya mendapat pendidikan yang layak pun harus menderita dan harus menerima bahwa tempat belajar mereka telah dibakar. Karena tidak diakui dan hak mereka pun tidak dihargai, akhirnya etnis Rohingya memilih untuk mengungsi ke beberapa negara. Namun, karena kekurangan transportasi, mereka menggunakan perahu-perahu dengan jumlah orang diluar kapasitas perahu. Akibatnya perahu pun tenggelam dan mengakibatkan banyak orang yang meninggal di laut. Etnis Rohingya juga mengalami kelaparan karena usaha-usaha mereka dibatasi oleh pemerintah Myanmar. Semua ini merupakan bentuk kejahatan genosida terhapa etnis Rohingya.

\section{Respons ASEAN dan Dunia Terhadap Pelanggaran Hak Asasi Manusia dalam Konflik Rohingya}

Konflik ini pada awalnya mulai terkuak di dunia internasional pada bulan Juli 2012 di mana pemberitaan media internasional mulai membuka fakta-fakta tentang adanya konflik Rohingya. Pada Juli 2012 konflik ini memuncak dengan adanya pembakaran besar-besaran terhadap perumahan yang dihuni oleh etnis Muslim Rohingya. Melihat kondisi yang terjadi, Perserikatan BangsaBangsa (PBB) dan Uni Eropa mengecam kekerasan yang terjadi pada konflik tersebut, namun hanya sekedar mengecam dan tidak menyalahkan pemerintah Myanmar. Lembaga lain seperti Amnesty Internasional dan Organisasi Hak Asasi Manusia (HAM) dunia menilai bahwa 
pemerintah Myanmar telah melakukan diskriminasi secara sistematis terhadap etnis Rohingya dan menyebabkan penderitaan yang tak kunjung usai (Triono, 2014: 3).

Myanmar merupakan wilayah yang masuk ke dalam regional Asia Tenggara. Adanya organisasi Association of Southeast Asian Nation (ASEAN) menjadi sebuah sarana bagi berkumpulnya 10 negara yang tergabung menjadi anggota ASEAN. Dalam permasalahan Rohingya yang terjadi di Myanmar, terutama Indonesia yang masuk ke dalam anggota ASEAN tidak tinggal diam. Bantuan kemanusiaan yang diberikan pemerintah Indonesia kepada pengungsi Rohingya di Aceh telah membuka mata dunia untuk ikut serta dalam membantu krisis kemanusiaan di Rohingya, Myanmar. Namun, dalam menghadapi konflik Rohingya harus berhati- hati hal ini dikarenakan ASEAN menganut prinsip nonintervensi yaitu prinsip untuk memastikan bahwa masalah tiaptiap negara harus diurus masingmasing tanpa adanya campur tangan dari pihak luar. Namun upaya-upaya yang telah dilakukan oleh ASEAN sebagai organisasi internasional antara lain berperan dalam mengelola konflik dan sejumlah kepala Negara ASEAN sepakat untuk menekan agar konfik bisa terselesaikan dan mengakhiri konflik antara etnis Budha dan Muslim (Triono, 2014: 9-10)

Selain itu, Organisasi Kerja sama Islam (OKI) juga melakukan beberapa kontribusi demi tersele- saikannya konflik yang terjadi di Rohingya. Antara lain, OKI sebagai mediator ketika pada tanggal 25 Juli 2012 setelah mendengar konflik hebat yang terjadi di Rakhine, Sekretaris Jenderal OKI Ihsanoglu yang menjabat pada saat itu langsung mengirimkan surat kepada Presiden Myanmar Thein Sein. Di dalam surat tersebut, berisi OKI mendesak kepada pe- merintah Myanmar untuk segera menyelesaikan konflik yang terjadi. Kemudian pada tanggal 10 Agustus 2012 OKI mengirimkan delegasinya ke Rakhine, Myanmar yaitu Ketua Palang Merah Indonesia Jusuf Kalla, Asisten Sekretaris Jendral OKI Atta El Mannan, Presiden Bulan Sabit Merah Qatar Muhammad Gahnim Al Mahdeed dan menemui Presiden Myanmar Thein Sein dan meminta agar bantuan kemanusiaan dari OKI bisa diterima oleh pengungsi di Rakhine, dan pada akhirnya pemerintah Myanmar menerima bantuan kemanusiaan dari OKI (Dewinta, 2016: 5). 


\section{Kesimpulan}

Dunia internasional tahun 2012 diwarnai oleh konflik yang terjadi di Myanmar yaitu konflik etnis Rohingya. Konflik yang terjadi di Myanmar sudah terjadi sejak lama namun media internasional baru mulai meliput tahun 2012 sehingga banyak negara mulai mengklaim tindakan pemerintah Myanmar. Akibat respon dunia internasional, konflik semakin memanas yang ditandai dengan pembunuhan, pemerkosaan dan pembakaran rumah-rumah warga etnis Rohingya. Selanjutnya konflik etnis antara Rohingya dan Rakhine tak mendapat titik damai. Upaya-upaya yang dilakukan oleh lembaga internasional maupun non internasional serta negara-negara, tidak membuat konflik itu terselesaikan. Justru semakin banyak tindakan kekerasan yang dilakukanterhadap etnis Rohingya. Semenjak diterbitkannya

kebijakan

burmanisasi, etnis Rohingya tidak diakui. Warga Rakhine dengan segala tindakan yang brutal berusaha melakukan segala cara untuk mengusir etnis Rohingya dari Myanmar. Kebijakan burmanisasi yang telah dikeluarkan membuat etnis Rohingya harus menjadi stateless atau tidak mempunyai kewarganegaraan.
Tindakan demi tindakan kekerasan diluncurkan kepada etnis Rohingya sehingga timbul rasa tidak nyaman yang mengharuskan etnis Rohingya harus mengungsi ke beberapa negara seperti Bangladesh, Indonesia, Malaysia dan Thailand. Tidak peduli banyaknya anak-anak yang harus mendapatkan kesempatan untuk hidup dan belajar, etnis Rakhine dan anggota militer Myanmar tetap melakukan serangan demi serangan terhadap etnis Rohingya. Memuncaknya konflik pada tahun 2012 membuat etnis Rohingya harus kehilangan keluarga, tempat tinggal bahkan harus mengungsi. Setelah itu tahuntahun berikutnya konflik itu tak kunjung redah. Justru semakin terjadi pembunuhan, pembakaran rumah -rumah dan tempat belajar hingga meningkatnya jumlah pengungsi di beberapa negara. Jumlah korban yang terus meningkat maka, konflik etnis yang terjadi di Myanmar termasuk dalam kejahatan genosida. Di mana, ada tindakan untuk memusnahkan etnis rohingya dari Myanmar dengan cara membunuh, membantai hingga tidak mengakui etnis Rohingya sebagai warga negara Myanmar. 


\section{Referensi}

Aluna, Hardi S.D dan M. Kholit Juani, 2017. Kebijakan Pemerintah Indonesia melalui Sekuritisasi Migrasi Pengungsi Rohingya di Aceh Tahun 20122015. Indonesian Perspective, Vol. 2, No,1 Januari-Juli

Ayu, Tiara Dewinta, 2016. Peran

Organisasi Kerja sama Islam (OKI) dalam Menangani Konflik Etnis RakhineRohingya di Myanmar Tahun 2012- 2013. Journal of International Relations, Vol. 2, No. 2. Fakultas Ilmu Sosial dan Politik Universitas Diponegoro Baehr, Pieter, dkk, 2001. Instrumen Internasional Pokok Hak-Hak Asasi Manusia. Yayasan Obor Indonesia, Jakarta.

Buyung, Adnan Nasution dan A.

Parta M. Zah, 2006. Instrumen Internasional Pokok Hak Asasi Manusia. Yayasan Obor Indonesia, Jakarta.

International Crisis Group Asia, 2014. Myanmar: The Politics of Rakhine State. 22 Oktober. Ichikaya, Gulia Mitzy, 2014. Perlawanan Etnis Muslim Rohingya terhadap Kebijakan Diskriminatif Pemerintah Burma-Myanmar. Indonesian
Journal of International Studies, Vol.1, No. 2 Desember

Nur, Sandy Ikfal Raharjo, 2015. Peran Identitas Agama dalam Konflik di Rakhine Myanmar Tahun 2012-2013. Jurnal Kajian Wilayah, Vol.6 No. 1. Yulia, Anna Hartati, 2013. Studi Eksistensi Etnis Rohingya di Tengah Tekanan Pemerintah Myanmar. Jurnal Hubungan Internasional, Vol. 2 No. 1.

Triono, 2014. Peran ASEAN

Dalam Penyelesaian Konflik Etnis Rohingya. Jurnal TAPIs Vol.10 No.2 Juli-Desember Susanti, Aviantina DKK, Penyelesaian Kasus pelanggaran HAM Berat Terhadap Etnis Rohingya di Myanmar Berdasarkan Hukum Internasional. Fakultas Hukum Universitas Brawijaya.

Turangan, Doortje D. “Tindakan Kejahatan Genosida dalam Ketentuan Hukum Internasional dan Hukum Nasional”. Karya Ilmiah.

\section{Internet}

6.700 Warga Rohingya Tewas dalam Bulan Pertama Kekerasan Myanmar diakses dari http://global.liputan6.com/ $\mathrm{read} / 3195783 / 6700$-wargarohingya-tewas-dalam-bulan- 
pertama-kekerasan-myanmar, diakses pada 17 Januari 2018

Data dan Fakta Tentang Rohingya, Arakan dan Rakhine diakses dari web http://www.islamedia. id/2012/08/data-dan-faktatentang-rohingya-arakan.html, diakses pada 22 januari 2018

Krisis terbaru Rohingya: bagaimana seluruh kekerasan bermula? diakses dari web http:// www. bbc . com/indonesia/ dunia-41105830, diakses pada 17 Januari 2018

Muslim Rohingya Pilih Mengungsi ke Indonesia, Begini Perlakuan Malaysia dan Thailand pada Mereka diakses dari http://medan.tribunnews. com/2017/09/05/muslimrohingya-pilih-mengungsi-keindonesia-begini-perlakuanmalaysia-dan-thailand-padamereka?page $=$ all, diakses pada 09 Februari 2018
Myanmar/Bangladesh: MSF surveys estimate that at least 6,700 Rohingya were killed during the attacks in Myanmar diakses dari http://www.msf.org/en/ article/myanmarbangladeshmsf-surveys-estimate-least6700-rohingya-were-killedduring-attacks, diakses pada 17 Januari 2018

Situation Report: Rohingya Refugee Crisis diakses dari https:// reliefweb.int/sites/reliefweb. int/files/resources/180127 weekly_iscg_sitrep_final.pdf, diakses pada 11 Februari 2018 
